\title{
Disparity Between Glucose-Dependent Insulinotropic Polypeptide and Insulin Responses in Obese Man
}

\author{
D. L.Sarson*, P.G. Kopelman ${ }^{2 * *}$, H.S. Besterman ${ }^{1 * * *}$, T. R. E. Pilkington ${ }^{2}$ and S. R. Bloom ${ }^{1}$ \\ 'Department of Medicine, Royal Postgraduate Medical School, Ducane Road, and \\ ${ }^{2}$ Department of Medicine, St Georges Hospital Medical School, London, UK
}

Summary. Studies were carried out in 32 obese patients and 30 normal-weight control subjects to ascertain the response of glucose-dependent insulinotropic polypeptide (GIP) and insulin to (1) oral and intravenous glucose ( 10 obese and 10 control subjects), (2) oral fat and intravenous glucose (eight obese and six control subjects) and (3) mixed test meal (14 obese and 14 control subjects). Basal mean insulin was higher in the obese $(99 \mathrm{pmol} / \mathrm{l})$ than in the control group $(40 \mathrm{pmol} / \mathrm{l})$, but fasting blood glucose and GIP were not significantly different from normal. The total integrated response of insulin in obese subjects after oral glucose was 54.1 versus $33.3 \mathrm{nmol} \cdot 1^{-1} \cdot \mathrm{h}^{-1}$ in control subjects; glucose and GIP responses were similar in both groups. After intravenous glucose the integrated insulin response was 8.8 in the obese versus $5.0 \mathrm{nmol} \cdot \mathrm{l}^{-1} \cdot \mathrm{h}^{-1}$ in control subjects; GIP was unaffected by intravenous glucose and glucose levels were similar. Following oral fat and intravenous glucose, insulin secretion was again abnormal in the obese, 24.5 versus $7.3 \mathrm{nmol} \cdot 1^{-1} \cdot \mathrm{h}^{-1}$ in controls, but GIP responses were normal. However, the control subjects became hypoglycaemic after this test: blood glucose $2.8 \mathrm{mmol} / 1$ at $150 \mathrm{~min}$ compared with $4.6 \mathrm{mmol} / 1$ in the obese group. The insulin response to a mixed meal was also abnormal in obesity.

Key words: Glucose-dependent insulinotropic polypeptide, insulin, obesity, glucose administration, fat administration, hypoglycaemia.
Obesity is characterised by fasting hyperinsulinaemia, and the ingestion of carbohydrate results in an exaggerated insulin response [1-4]. One explanation for this is that an increased caloric intake produces B cell hyperplasia with consequent insulin hypersecretion [5]. Recent reports $[6,7]$ suggest that the enteroinsular axis is overactive in obesity. Glucose-dependent insulinotropic polypeptide (GIP) has been proposed as a major mediator of the enterically induced component of insulin secretion [8]. Evidence for the involvement of GIP in the enteroinsular axis has mounted steadily in recent years, and it is natural to explore the role of this hormone in the aetiology of obesity.

The present studies were designed to investigate the release of GIP in obese patients in response to the major secretagogues of this hormone. In addition, the extent of the rôle of GIP in the exaggerated insulin re-

\footnotetext{
Present Addresses:

* Dr. D. L. Sarson, Cyanamid International, Clinical Research (European Region), Shearwater House, Richmond, Surrey, UK

** Dr. P.G. Kopelman, Department of Medicine, The London Hospital Medical College, Whitechapel Road, London, UK

*** Dr. H.S. Besterman, Department of Endocrinology, St Bartholomew's Hospital, West Smithfield, London, UK
}

sponse in obesity is examined by determination of the insulin response to both intravenous and oral glucose. Since GIP is unaffected by intravenous glucose, any difference in insulin response after this stimulus must be due to factors other than GIP.

\section{Patients and Methods}

The studies were carried out on 32 obese subjects ( 24 women and eight men) all of whom had normal glucose tolerance, and 30 agematched volunteers of normal weight (18 women and 12 men). Informed consent was obtained from each subject, and at the time of the investigation none was taking any medication. Both groups ate an unrestricted diet, containing at least $200 \mathrm{~g}$ of carbohydrate a day, for 1 week before investigation. Clinical details are shown in Table 1. Ideal body weight was derived from the Metropolitan Life Insurance Company Tables [9]. Obese and control subjects were randomly divided into sub-groups for each set of experiments. Some subjects underwent more than one investigation, but in such cases at least 1 week elapsed between experiments.

\section{Oral Glucose Load}

Each subject was given a drink containing $100 \mathrm{~g}$ glucose in $300 \mathrm{ml}$ water. Blood samples were taken at $-30,-15,0,15,45,60$ and $120 \mathrm{~min}$. 
Table 1. Clinical characteristics of subjects studied in obesity investigations

\begin{tabular}{|c|c|c|c|c|}
\hline Test & Subjects & $\begin{array}{l}\text { Mean } \\
\text { age } \\
\text { (years) }\end{array}$ & Range & $\begin{array}{l}\% \text { Ideal } \\
\text { body } \\
\text { weight }\end{array}$ \\
\hline $\begin{array}{l}100 \mathrm{~g} \text { oral glucose } \\
\text { load }\end{array}$ & Control $(n=10)$ & 32 & $24-40$ & $98 \pm 3$ \\
\hline $\begin{array}{l}20 \mathrm{~g} \text { IV glucose } \\
\text { infusion }\end{array}$ & Obese $(n=10)$ & 30 & $17-38$ & $215 \pm 5$ \\
\hline \multirow[t]{2}{*}{ Mixed test meal } & Control $(n=14)$ & 33 & $23-46$ & $106 \pm 5$ \\
\hline & Obese $(n=14)$ & 35 & $25-52$ & $225 \pm 7$ \\
\hline \multirow{2}{*}{$\begin{array}{l}\text { Oral fat }+ \text { IV } \\
\text { glucose infusion } \\
\text { and IV glucose } \\
\text { infusion alone }\end{array}$} & Control $(n=6)$ & 30 & $27-34$ & $102 \pm 4$ \\
\hline & Obese $(n=8)$ & 31 & $27-38$ & $230 \pm 6$ \\
\hline
\end{tabular}

Results expressed as mean \pm SEM

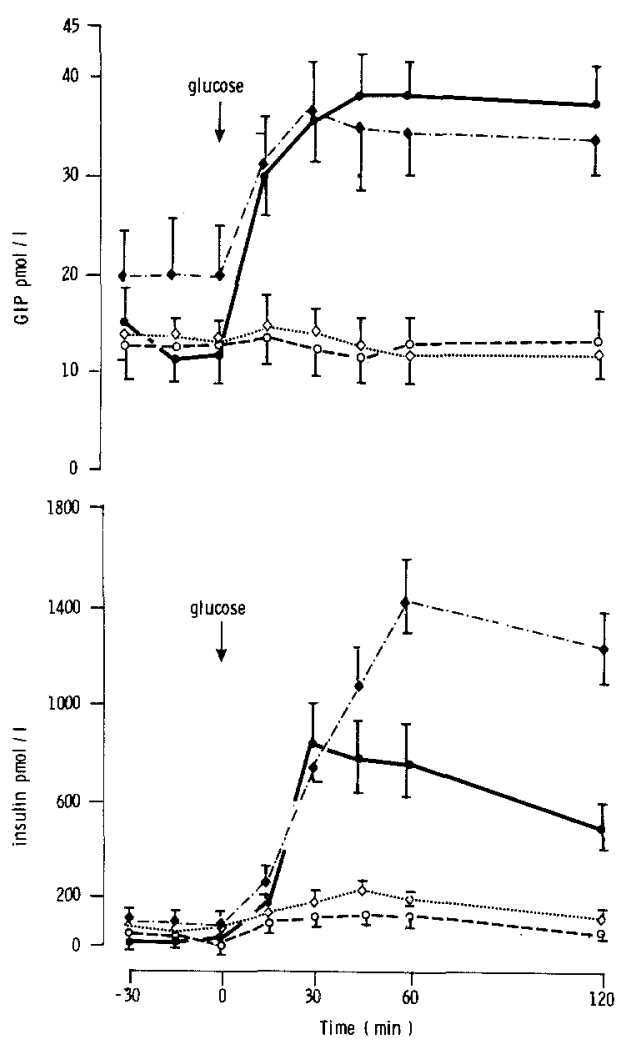

Fig. 1. The response of plasma GIP (top panel) and insulin (bottom panel) in 10 obese $(\bullet)$ and 10 normal weight control subjects $(\bullet)$ to oral glucose, and in the same obese $(\vartheta)$ and normal-weight $(O)$ subjects to intravenous glucose. Values are expressed as mean \pm SEM

\section{Intravenous Glucose}

A $10 \%$ solution of $20 \mathrm{~g}$ glucose in $0.9 \%$ saline was infused into the antecubital fossa of one arm by means of a variable-rate, constant-velocity syringe ram pump (Harvard Instruments, Millis, Massachusetts, USA). Arterialised capillary blood samples were taken from a warmed hand for glucose estimation using glucose oxidase strips (Dextrostix, Ames, Stoke Poges, UK) and a portable photometer (Hypocount, Hypoguard, Suffolk, UK). The glucose infusion rate was changed according to the results from the glucose oxidase strips so as to follow the oral glucose curve. Blood was drawn from the contralateral arm at the same time intervals as in the oral glucose test.

\section{Mixed Test Meal}

Each subject was given a mixed test breakfast of $2225 \mathrm{~kJ}$ ( $18 \mathrm{~g}$ protein, $22 \mathrm{~g}$ fat and $66 \mathrm{~g} \mathrm{CHO})(10)$. Blood samples were taken before $(-30$, $-15 \mathrm{~min})$, at the start $(0 \mathrm{~min})$ and after ingestion of the meal $(15,30$, 120 and $180 \mathrm{~min}$ ). In all cases the meal was consumed within $15 \mathrm{~min}$.

\section{Oral Fat Followed by Intravenous Glucose}

Fat was given as $214 \mathrm{ml}$ of unsweetened double cream consisting of $100.0 \mathrm{~g}$ fat, $3.1 \mathrm{~g}$ protein and $4.1 \mathrm{~g}$ carbohydrate. Two blood samples were taken before the ingestion of fat, and thereafter at $15 \mathrm{~min}$ intervals for $1 \mathrm{~h}$. At this time, an IV glucose infusion (as described above) was given. Further blood samples were drawn at 75, 90, 105, 150 and $180 \mathrm{~min}$.

\section{Treatment of Blood Samples}

Venous blood was drawn from an indwelling $19 \mathrm{G}$ butterfly cannula in the antecubital fossa. The catheter was kept patent by equal volumes of $0.9 \%$ saline solution and $3.8 \%$ sodium citrate solution. For blood glucose measurement, $2.5-\mathrm{ml}$ samples of whole blood were taken into fluoride oxalate tubes and kept refrigerated $\left(+4^{\circ} \mathrm{C}\right)$ until assay. For hormone estimation $10-\mathrm{ml}$ samples of whole blood were taken into chilled heparin tubes containing aprotinin (Trasylol, Bayer, FRG). This blood was immediately centrifuged for 5-10 min at $1600 \mathrm{~g}$, and the plasma was then stored at $-20^{\circ} \mathrm{C}$ until assay.

\section{Plasma Hormone Measurements}

Insulin was measured using commercially-obtainable ${ }^{125}$ I-insulin (IM530 The Radiochemical Centre, Amersham, Bucks, UK) and guinea-pig anti-insulin serum (Wellcome), with a standard curve set up in plasma stripped of endogenous insulin by charcoal adsorption. The sensitivity of the assay was $6 \mathrm{pmol} / \mathrm{l}$. GIP was estimated by radioimmunoassay [11]. The antiserum (GIP 19) was raised using carbodiimide condensation to haemocyanin. ${ }^{125}$ I-labelled-GIP was prepared by a modified enzymatic method using lactoperoxidase oxidation. The specific activity of this preparation was between 55 and $75 \mathrm{~Bq} / \mathrm{fmol}$. In the absence of added GIP, the antiserum used at a final dilution of $1: 96000$ bound approximately $50 \%$ of the $1.5 \mathrm{fmol}$ of ${ }^{125}$ I-labelled GIP added to each assay tube. Standard curve plasma was prepared by removing endogenous GIP by specific immunoadsorption. The molecular species of GIP recognised by the antiserum were analysed by gel permeation chromatography. Two major peaks were identified, the first eluting soon after cytochrome-C (Kav $0.3 \pm$ $0.02, n=5)$ and the other co-eluting with pure porcine standard GIP (Kav $0.67 \pm 0.02$ ). The percentage of large GIP (large + small GIP being $100 \%$ ) for the following conditions was: fasting plasma $73 \pm 9.6$ (mean \pm SEM), after glucose $27 \pm 5.8$, after fat $49 \pm 8$ and after a mixed meal $40 \pm 5 ;(n=5)$. The antibody demonstrated $<1 \%$ cross reactivity with glucagon and none with other gastrointestinal hormones. The sensitivity of the assay allowed changes of $3 \mathrm{pmol} / 1 \mathrm{GIP}$ ( $\pm 2 \mathrm{SD}$ of the zero standard) to be detected between individual adjacent plasma samples.

Blood glucose was measured by the method of Gutteridge and Wright [12].

\section{Statistical Analyses}

Individual datum points are expressed as mean $\pm \mathrm{SEM}(\mathrm{df}=n-1)$. Integrated responses were calculated as total integrated response (TIR). TIR is the total area of the polygon under the response curve. Significance was assessed by Student's t-test on a paired basis for intragroup and unpaired for inter-group comparisons.

The enteroinsular component was measured as the total incremental integrated response after oral glucose divided by the total incremental integrated response after intravenous glucose. 
Table 2. Mean blood glucose in obese subjects and in normal weight control subjects after $100 \mathrm{~g}$ oral glucose, $20 \mathrm{~g}$ intravenous glucose and a mixed test meal

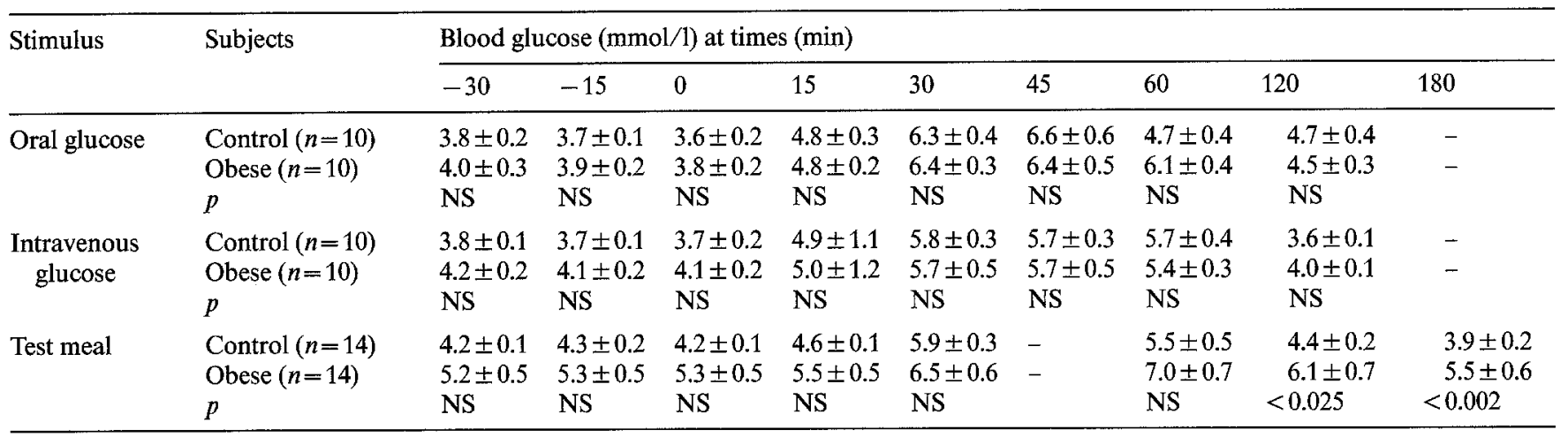

Results expressed as mean \pm SEM
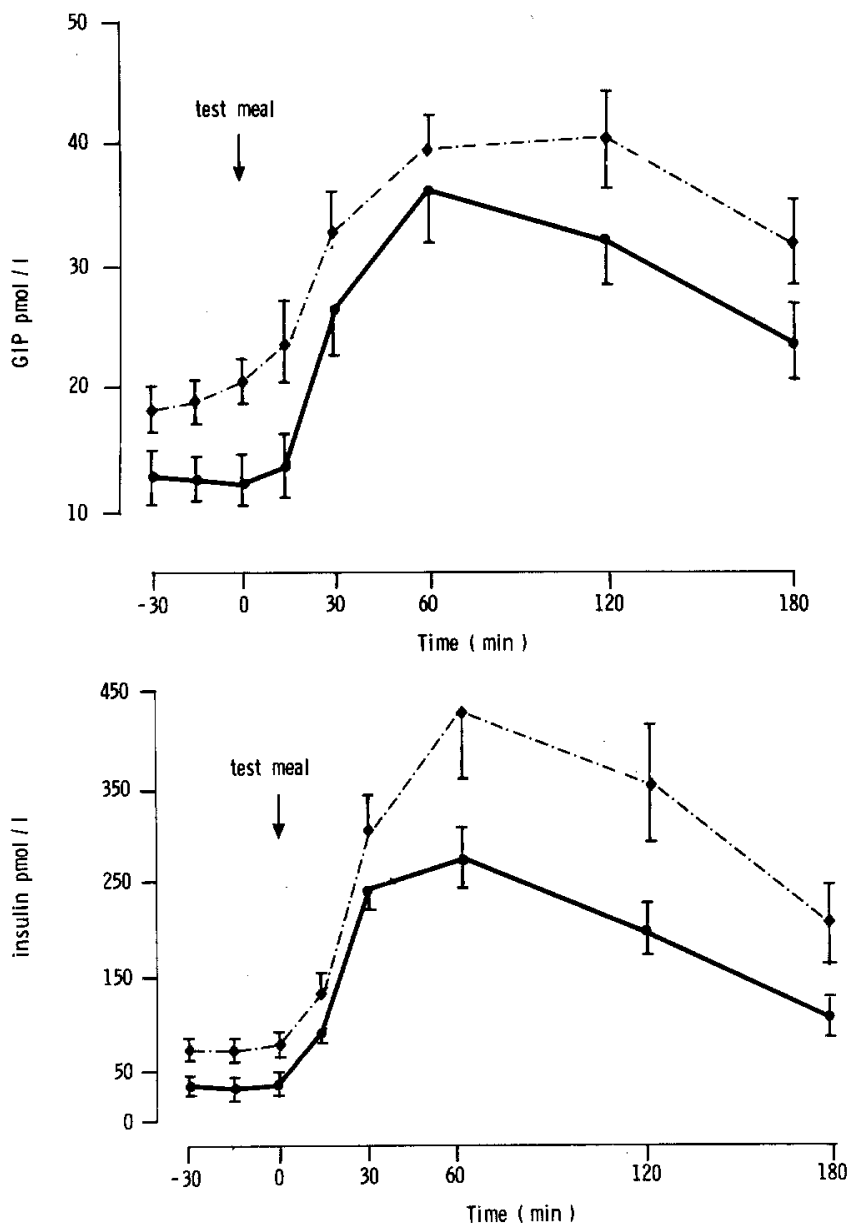

Fig. 2. The response of plasma GIP (top panel) and insulin (bottom panel) to a mixed test meal in 14 obese patients (broken line) and 14 normal-weight control subjects (solid line). All values expressed as mean \pm SEM

\section{Results}

\section{Oral Versus Intravenous Glucose}

The responses of GIP and insulin to each stimulus are shown in Figure 1. There was no statistically significant difference between the obese and control groups in GIP or glucose, either basally or after either glucose stimulus (Table 2). GIP remained at basal levels throughout the intravenous glucose test. Blood glucose was similar after both oral and intravenous glucose. The obese group had basal hyperinsulinaemia and exaggerated insulin responses to both oral and intravenous glucose. The enteroinsular component was similar in the obese and control groups. The insulin response to oral glucose in both groups was six times as great as that seen after intravenous glucose.

\section{Test Meal}

The responses of GIP and insulin to the test meal are shown in Figure 2. The basal GIP was slightly higher in the obese group and this gave rise to a significantly higher GIP at $15 \mathrm{~min}$. The degree of response, however, was similar in both groups. Basal insulin was augmented in the obese group and once again the response to food resulted in an exaggeration of plasma concentrations of this hormone. Fasting blood glucose was similar in both groups, but towards the end of the experiment significantly greater glucose levels were seen in obesity.

\section{Oral Fat with Intravenous Glucose, Versus Intravenous Glucose}

Mean concentrations of GIP and insulin over the course of the experiment are shown in Figure 3, and those of glucose in Table 3. GIP concentrations were similar in both groups for each test and were, if anything more augmented in the control group. A biphasic response of GIP was noted in the control group. The glucose response to intravenous glucose was similar in both groups. However, after fat and intravenous glucose the control subjects developed significant hypoglycaemia at the conclusion of the test. As with the other tests both basal and stimulated insulin concentrations were higher in the obese group. The insulin response to fat and intravenous glucose was greater in both groups 
Table 3. Mean blood glucose in obese subjects and in normal weight control subjects after $100 \mathrm{~g}$ oral fat (as unsweetened cream) and $20 \mathrm{~g}$ intravenous glucose or after $20 \mathrm{~g}$ intravenous glucose alone

\begin{tabular}{|c|c|c|c|c|c|c|c|c|c|c|c|c|c|}
\hline \multirow[t]{2}{*}{ Stimulus } & \multirow[t]{2}{*}{ Subjects } & \multicolumn{12}{|c|}{ Blood glucose $(\mathrm{mmol} / \mathrm{l})$ at times $(\mathrm{min})$ : } \\
\hline & & -15 & 0 & 15 & 30 & 45 & 60 & 75 & 90 & 105 & 120 & 150 & 180 \\
\hline \multirow{3}{*}{$\begin{array}{l}\text { Oral fat } \\
+ \text { IV } \\
\text { glucose }\end{array}$} & $\begin{array}{l}\text { Control } \\
(n=6)\end{array}$ & $4.1 \pm 0.2$ & $4.1 \pm 0.1$ & $4.1 \pm 0.1$ & $4.0 \pm 0.1$ & $3.8 \pm 0.1$ & $3.6 \pm 0.1$ & $5.0 \pm 0.1$ & $6.8 \pm 0.6$ & $6.4 \pm 0.6$ & $5.8 \pm 0.3$ & $2.8 \pm 0.1$ & $2.9 \pm 0.2$ \\
\hline & $\begin{array}{l}\text { obese } \\
(n=8)\end{array}$ & $4.5 \pm 0.2$ & $4.4 \pm 0.2$ & $4.5 \pm 0.2$ & $4.5 \pm 0.2$ & $4.3 \pm 0.2$ & $4.1 \pm 0.2$ & $5.4 \pm 0.2$ & $6.2 \pm 0.3$ & $6.5 \pm 0.3$ & $6.8 \pm 0.4$ & $4.6 \pm 0.3$ & $3.9 \pm 0.2$ \\
\hline & $p$ & NS & NS & NS & NS & NS & NS & NS & NS & NS & NS & $<0.005$ & $<0.05$ \\
\hline & $\begin{array}{l}\text { Obese } \\
(n=8)\end{array}$ & - & - & - & - & $4.3 \pm 0.2$ & $4.5 \pm 0.2$ & $5.8 \pm 0.4$ & $6.8 \pm 0.4$ & $7.2 \pm 0.3$ & $7.5 \pm 0.5$ & $5.4 \pm 0.3$ & $4.2 \pm 0.1$ \\
\hline & $p$ & & & & & NS & NS & NS & NS & NS & NS & NS & NS \\
\hline
\end{tabular}

Results expressed as mean \pm SEM
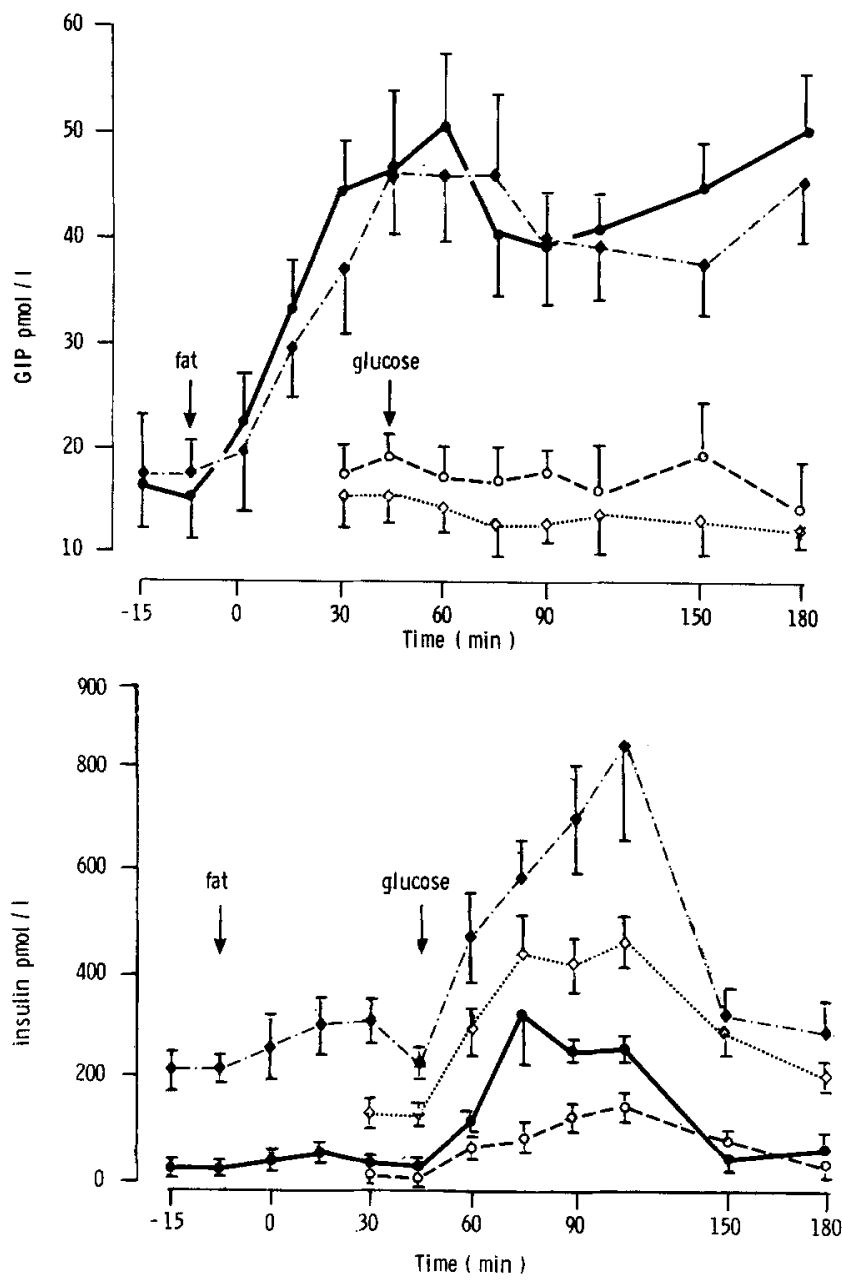

Fig. 3. The response of GIP (top panel) and insulin (bottom panel) in eight obese patients following oral fat and intravenous glucose $(\bullet)$ or intravenous glucose alone $(\diamond)$ and in six normal-weight control subjects to oral fat and intravenous glucose $(\boldsymbol{O})$ or intravenous glucose alone $(O)$. All values expressed as mean \pm SEM

than after intravenous glucose alone (peak insulin in controls after fat and intravenous glucose; $323 \pm$ $100 \mathrm{pmol} / \mathrm{l}$, after intravenous glucose $=150 \pm 32$ pmol/1, $p<0.01$; peak insulin in obesity after fat/intravenous glucose $=840 \pm 214 \mathrm{pmol} / 1$, after intravenous glucose $=465 \pm 52 \mathrm{pmol} / 1, p<0.05)$ and this represented an approximate twofold difference in each case.

\section{Inter-Experiment Comparison}

The integrated responses of GIP, insulin and blood glucose for each experiment are given in Table 4 . In spite of similar GIP and glucose concentrations the insulin response of the control subjects to fat and intravenous glucose was significantly lower (TIR $7.3 \pm 1 \mathrm{nmol} \cdot 1^{-1}$. $\mathrm{h}^{-1}$ ) than after oral glucose (TIR $33.6 \pm 6 \mathrm{nmol}^{-1} 1^{-1}$. $\left.\mathrm{h}^{-1}, p<0.001\right)$. The pattern was similar in obesity with reduced insulin secretion to fat and intravenous glucose (TIR $24.5 \pm 3.3 \mathrm{nmol} \cdot \mathrm{l}^{-1} \cdot \mathrm{h}^{-1}$ compared to that seen after oral glucose (TIR $54.1 \pm 6.5 \mathrm{nmol} \cdot 1^{-1} \cdot \mathrm{h}^{-1}, p<0.01$ ) in spite of a better GIP response to fat.

\section{Discussion}

During all the experiments detailed above, there was no difference in the magnitude of the GIP response between subjects who were grossly obese and normal weight controls. In contrast the basal insulin and the insulin response to all stimuli was dramatically elevated in obesity. Previous reports have shown markedly increased GIP secretion in obesity after ingestion of a liquid mixed meal or triglycerides $[6,7,13]$ and it has been proposed that this is brought about by a defect in the feedback mechanism of insulin on the GIP cell. This, in turn, may be related to the increased peripheral insulin resistance.

The increased GIP secretion reported in obesity following oral fat, however, cannot be attributed to this mechanism since fat-mediated GIP release does not of itself potentiate insulin secretion. It is difficult to compare directly the results reported here with those of others. Firstly, the absolute values of GIP found in the circulation in both the fasting and the stimulated are markedly lower when measured with the assay used here [11], than those obtained using assays reported earlier [13-15] although they are comparable to more re- 
Table 4. Total integrated responses of GIP, insulin and blood glucose in obesity and normal weight control subjects

\begin{tabular}{|c|c|c|c|}
\hline Stimulus & $\begin{array}{l}\text { Hormone/ } \\
\text { glucose }\end{array}$ & Subject $(n)$ & $\begin{array}{l}\text { Total } \\
\text { integrated } \\
\text { response } \\
\left(\mathrm{nmol} \cdot \mathrm{l}^{-1} \cdot \mathrm{h}^{-1}\right)\end{array}$ \\
\hline \multirow[t]{3}{*}{$100 \mathrm{~g}$ oral glucose } & GIP & $\begin{array}{l}\text { Control (10) } \\
\text { Obese }(10)\end{array}$ & $\begin{aligned} & 2.2 \pm 0.2 \\
& 1.6 \pm 0.2 \\
& \text { NS }\end{aligned}$ \\
\hline & Insulin & $\begin{array}{l}\text { Control (10) } \\
\text { Obese (10) }\end{array}$ & $\begin{array}{l}33 \quad \pm 6 \\
54 \quad \pm 7 \\
p<0.05\end{array}$ \\
\hline & Glucose $e^{a}$ & $\begin{array}{l}\text { Control (10) } \\
\text { Obese (10) }\end{array}$ & $\begin{array}{l}0.30 \pm 0.02 \\
0.35 \pm 0.02 \\
\mathrm{NS}\end{array}$ \\
\hline \multirow[t]{3}{*}{$\begin{array}{l}20 \mathrm{~g} \text { intravenous } \\
\text { glucose }\end{array}$} & GIP & $\begin{array}{l}\text { Control (10) } \\
\text { Obese (10) }\end{array}$ & $\begin{array}{c}1.0 \pm 0.3 \\
0.8 \pm 0.2 \\
\mathrm{NS}\end{array}$ \\
\hline & Insulin & $\begin{array}{l}\text { Control (10) } \\
\text { Obese }(10)\end{array}$ & $\begin{array}{c}5.0 \pm 1.0 \\
8.8 \pm 1.0 \\
p<0.001\end{array}$ \\
\hline & Glucose $^{a}$ & $\begin{array}{l}\text { Control (10) } \\
\text { Obese (10) }\end{array}$ & $\begin{array}{l}0.30 \pm 0.02 \\
0.30 \pm 0.02 \\
\text { NS }\end{array}$ \\
\hline \multirow[t]{3}{*}{$\begin{array}{l}\text { Oral fat } \\
\text { intravenous } \\
\text { glucose }\end{array}$} & GIP & $\begin{array}{l}\text { Control (6) } \\
\text { Obese (8) }\end{array}$ & $\begin{array}{c}2.8 \pm 0.3 \\
2.2 \pm 0.2 \\
\text { NS }\end{array}$ \\
\hline & Insulin & $\begin{array}{l}\text { Control (6) } \\
\text { Obese (8) }\end{array}$ & $\begin{array}{l}7.3 \pm 1.0 \\
24.5 \pm 3.3 \\
p<0.001\end{array}$ \\
\hline & Glucose $^{a}$ & $\begin{array}{l}\text { Control (6) } \\
\text { Obese (8) }\end{array}$ & $\begin{array}{c}0.4 \pm 0.01 \\
0.3 \pm 0.01 \\
\mathrm{NS}\end{array}$ \\
\hline \multirow[t]{3}{*}{$\begin{array}{l}\text { Intravenous } \\
\text { glucose }\end{array}$} & GIP & $\begin{array}{l}\text { Control (6) } \\
\text { Obese (8) }\end{array}$ & $\begin{array}{c}1.4 \pm 0.4 \\
0.9 \pm 0.2 \\
\text { NS }\end{array}$ \\
\hline & Insulin & $\begin{array}{l}\text { Control (6) } \\
\text { Obese (8) }\end{array}$ & $\begin{array}{l}6.4 \pm 1.0 \\
18.2 \pm 0.2 \\
p<0.002\end{array}$ \\
\hline & Glucose $\mathrm{e}^{\mathrm{a}}$ & $\begin{array}{l}\text { Control (6) } \\
\text { Obese (8) }\end{array}$ & $\begin{array}{cc}0.3 \pm 0.02 \\
0.3 \pm 0.03 \\
\text { NS }\end{array}$ \\
\hline \multirow[t]{3}{*}{ Test meal } & GIP & $\begin{array}{l}\text { Control (14) } \\
\text { Obese (14) }\end{array}$ & $\begin{array}{l}1.8 \pm 0.25 \\
2.2 \pm 0.2\end{array}$ \\
\hline & Insulin & $\begin{array}{l}\text { Control (14) } \\
\text { Obese (14) }\end{array}$ & $\begin{array}{l}19.0 \pm 3.0 \\
26.3 \pm 1.2 \\
p<0.05\end{array}$ \\
\hline & Glucose $^{a}$ & Control (14) & $\begin{array}{l}0.23 \pm 0.02 \\
0.30 \pm 0.02 \\
\text { NS }\end{array}$ \\
\hline
\end{tabular}

a Glucose is expressed as mmol $\cdot 1^{-1} \cdot \mathrm{h}^{-1}$. Results expressed as mean \pm SEM

cently reported results [16]. The reason for this disparity probably relates to the greater sensitivity and specificity of the antibody used here (GIP 19).

Secondly, differences exist in the type and amount of stimulus to GIP release used in the various other studies. No difference can be found in the response of GIP between obese subjects and normal weight controls after giving the two major stimulants (fat and carbohydrate) either individually, or as a mixture in the meal. The comparison between intravenous and oral glucose studies is of considerable interest. By matching the glucose curves for both situations the behaviour of the enteroinsular axis and the role of GIP could be observed. The enteroinsular component, that is, the ratio of the insulin responses to oral and intravenous glucose, was $6: 1$ in both obese and normal weight subjects, although Perley and Kipnis found a ratio of $3: 1$ [17] and Lauritsen et al. 4:1 [18]. The absolute quantities of insulin involved, however, were substantially different, while the GIP response was identical and showed no depression, even though, according to previously reported results, any postulated insulin feedback mechanism on GIP secretion should be present at least in normal weight controls $[6,13]$.

The results of these studies raise certain questions as to the importance of GIP in the control of insulin secretion, since the insulin response seen after the fat and intravenous glucose was considerably smaller than after oral glucose. Because the GIP concentrations were somewhat higher and the blood glucose levels closely similar to those seen after oral glucose, a similar insulin rise would have been predicted. There are three possible explanations for this discrepancy: firstly, that GIP plays only a minor role in the release of insulin; secondly that fat releases an inhibitor to insulin release; thirdly that fat stimulates a different molecular species of GIP which has limited insulinotropic activity. Since fat alone was not given after insulin stimulation, the second possibility cannot yet be answered. Preliminary investigations by gel chromatography have shown that similar absolute quantities of the 5000-dalton form of GIP were present after both glucose and fat stimulation [11]. Clearly further work is required to provide firm conclusions regarding the humoral control of the enteroinsular response.

The biphasic response of GIP noted in the oral fat intravenous glucose experiment is in agreement with earlier studies $[6,19]$, but the underlying mechanism is, as yet, unexplained, and may reflect insulin feedback on GIP secretion or the late release of a different molecular species of this hormone.

An interesting, but unexpected, finding was that of reactive hypoglycaemia in the control subjects on discontinuation of the intravenous glucose infusion which followed the ingestion of fat. Previous studies have failed to show this effect when fat and intravenous glucose were administered. However, all but one of these $[6,19]$ gave fat on a background of hyperglycaemia while the other study [20] was of fat followed by a bolus injection of glucose; thus differences in protocol may be responsible. All the normal volunteers used for the fat/glucose experiment reported sensations of 'lightheadedness', hunger and tremor and, in each case, this was associated with substantially reduced blood glucose concentrations. It is of interest that the nadir of glucose was concomitant with the secondary rise of GIP at the end of the experimental regimen. Although no detailed data exist, two previous reports [21, 22] have suggested that GIP release may be involved in the development of reactive hypoglycaemia. Thomford et al. [21] 
attributed the late phase of dumping seen after vagotomy and pyloroplasty to an increased GIP release found in these patients, and Cataland [22] also reported increased GIP secretion in cases of reactive hypoglycaemia after glucose administration. In the present study no finding of increased GIP release was made in the controls who experienced hypoglycaemia. The absence of hypoglycaemia in obese subjects is interesting and may be due to the peripheral insulin resistance characteristic of obesity [23].

Acknowledgements. The authors wish to thank the Wellcome Foundation and The British Diabetic Association for generous financial assistance. They would also like to thank Miss P. Dayus and the Dietetic Department of the Hammersmith Hospital for their assistance.

\section{References}

1. Karam JH, Grodsky GM, Forsham PH (1963) Excessive insulin response to glucose in obese subjects as measured by immunochemical assay. Diabetes 12: 197-205

2. Yalow RS, Glick SM, Roth J, Berson SA (1965) Plasma insulin and growth hormone levels in obesity and diabetes. Ann N Y Acad Sci 131: 357-373

3. Bagdade JD, Bierman EL, Porte D (1967) The significance of basal insulin in the evaluation of the insulin response to glucose in diabetic and non diabetic subjects. J Clin Invest 46: 1549-1557

4. Kreisberg RA, Boshell BR, DiPlacido J, Roddam RF (1967) Insulin secretion in obesity. N Engl J Med 276: 314-319

5. Grey NJ, Kipnis DM (1971) Effect of diet composition on the hyperinsulinaemia of obesity. New Engl J Med 285: 827-831

6. Creutzfeldt W, Ebert R, Willms B, Frerichs H, Brown JC (1978) Gastric inhibitory polypeptide (GIP) and insulin on obesity: increased response to stimulation and defective control of serum levels. Diabetologia 14: 15-24

7. Ebert R, Willms B, Brown JC, Creutzfeldt W (1976) Serum gastric inhibitory polypeptide (GIP) levels in obese subjects and after weight reduction. Eur J Clin Invest 6:327 (Abstract)

8. Creutzfeldt W (1974) Insulin-releasing factors of the gastrointestinal mucosa (incretin). Gastroenterology 67: 748-750

9. Stat Bull Metrop Life Ins Co 40 (1959)

10. Besterman HS, Bloom SR, Sarson DL, Blackburn AM, Johnston DI, Patel HR, Stewart JS, Modigliani R, Guerin S, Mallison CN (1978) Gut hormone profile in coeliac disease. Lancet 1: 785-788
11. Sarson DL, Bryant MG, Bloom SR (1980) A radioimmunoassay for gastric inhibitory polypeptide in human plasma. $J$ Endocrinol 85: $487-496$

12. Gutteridge JMC, Wright EB (1968) A simple automated guaiacum glucose-oxidase method. J Med Lab Technol 25: 385-386

13. Ebert R, Frerichs H, Creutzfeldt W (1979) Impaired feedback control of fat induced gastric inhibitory polypeptide (GIP) secretion by insulin in obesity and glucose intolerance. Eur $\mathbf{J}$ Clin Invest 9: 129-135

14. Kuzio M, Dryburgh JR, Malloy KM, Brown JC (1974) Radioimmunoassay for gastric inhibitory polypeptide. Gastroenterology $66: 357-364$

15. Morgan LM, Morris BA, Marks V (1978) Radioimmunoassay of gastric inhibitory polypeptide. Ann Clin Biochem 15: 172-177

16. McLoughlin JC, Buchanan KD, Alam MJ (1979) A glucose-hydrolase inhibitor in treatment of dumping syndrome. Lancet 2 : 603-605

17. Perley MJ, Kipnis DM (1967) Plasma insulin responses to oral and intravenous glucose: Studies in normal and diabetic subjects. J Clin Invest 46: 1954-1962

18. Lauritsen KB, Moody AJ, Christensen KC, Lindkaer-Jensera S (1980) Gastric inhibitory polypeptide (GIP) and insulin release after small bowel resection in man. Scand J Gastroenterol 15: 833-840

19. Brown JC, Dryburgh JR, Ross SA, Dupre J (1975) Identification and actions of gastric inhibitory polypeptide. Rec Progr Horm Res 31: 487-532

20. Ross SA, Dupre J (1978) Effects of ingestion of triglyceride or galactose on secretion of gastric inhibitory polypeptide and on responses to intravenous glucose in normal and diabetic subjects. Diabetes 27: 327-333

21. Thomford NR, Sirinek KR, Crockett SE, Mazzaferri EL, Cataland S (1974) Gastric inhibitory polypeptide. Response to oral glucose after vagotomy and pyloroplasty. Arch Surg 109: 177-182

22. Cataland S (1975) Personal communication - Discussion. Rec Progr Horm Res 31: 526-527

23. Rabinowitz D (1968) Hormonal profile and forearm metabolism in human obesity. Am J Clin Nutr 21: 1438-1444

Received: 4 October 1982

and in revised form: 17 July 1983

Professor S. R. Bloom

Department of Medicine

Royal Postgraduate Medical School

Ducane Road

London W12 OHS

UK 